\title{
Independent Prognostic Factors of Burns Injury and Evaluation of RPR as an Important Risk Factor
}

\author{
Kirti Panwar'1, Amit Yadav², Sheetal Arora ${ }^{3}$, Meenakshi Shankar ${ }^{4}$
}

Section: Healthcare

Sci. Journal Impact

Factor: 6.1 (2018)

ICV: 90.90 (2018)

(c) (i) (3)

Copyright@IJCRR

\begin{abstract}
Senior Resident, Department of Pathology, Vardhman Mahavir Medical College and Safdarjung Hospital, Delhi, India; ${ }^{2}$ Professor, Department of Pathology, Vardhman Mahavir Medical College and Safdarjung Hospital, Delhi, India; ${ }^{3}$ Associate Professor, Department of Pathology, Vardhman Mahavir Medical College and Safdarjung Hospital Delhi, India; 4 Senior Resident, Department of Pathology, Vardhman Mahavir Medical College and SafdarjungHospital Delhi, India.
\end{abstract}

\section{ABSTRACT}

Background: Injuries from burn remain the second largest group of injuries after road traffic accidents. Approximately 1-1. 5 lakh people die from burns and around 2.8lakh people require multiple surgeries and prolonged rehabilitation.

Objectives: To evaluate independent prognostic factors of burns injury and evaluation of RPR as an important risk factor.

Methods: The present retrospective study patients of all age groups admitted to burns department from 1 st March 2018 to 31 st May 2018 with variable \%TBSA burned were included. For 100 patients noted the clinical details like age, gender, burn index, inhalation injury if present, complete blood count, blood urea and serum creatinine levels. Medical notes were used to retrospectively record the patients. Their blood samples were routinely collected between 5 am and 7 am during 5 th, 7 th, 10 th and 20th-day post-burn. The medical records were used to document the time from injury to adverse events.

Results: The age, \% of burns, RDW, RPR, MPV, WBC, urea and creatinine values were considerably high in patients with mortality in the day 5 , day 7 , day 10 and day 20 datasets, whereas the haemoglobin, platelet values were low.

Conclusion: In this study, results indicated that parameters like haemoglobin, RDW, blood urea and serum creatinine and \% of burns are statistically significant independent mortality predictors in burn patients. Whereas, RPR did not prove to be a statistically significant independent mortality predictor.

Key Words: Burn Injuries, independent Prognostic factors, RDW to platelet ratio, Burn injuries, Multiple surgeries

\section{INTRODUCTION}

India is the second-most populous country in the world with a population of more than 125 crores and has an estimated annual burn incidence of 6-7 million. Injuries from burn remain the second largest group of injuries after road traffic accidents. Nearly $10 \%$ of burn injuries are life-threatening and require hospitalization. Around $25 \%$ of those hospitalized gradually succumb to their injuries. Approximately 1-1.5 lakh people die from burns and around 2.8 lakh people require multiple surgeries and prolonged rehabilitation. ${ }^{1}$ Burns is a three-dimensional injury and its severity depends on the quantum and depth of tissue burnt. The whole body surface area is taken as $100 \%$. The proportion of surface burns is represented as a percentage. Rule of nine popularized by A.F Wallace of Edinburg is the most popular method of describing the surface burn. Lund and Browder's chart is used for

\section{Corresponding Author:}

Dr. Amit Yadav, Professor, Department of Pathology, Vardhman Mahavir Medical College and Safdarjung Hospital, Delhi, India. Email: amityadav7284@yahoo.co.in

ISSN: 2231-2196 (Print)

Received: 28.07 .2020

ISSN: $0975-5241$ (Online)

Revised: 10.10 .2020

Accepted: 30.10 .2020

Published: 14.12 .2020 
helps in describing the surface area of the burn. This body is divided into 11 equal parts; making this $99 \%$ and $1 \%$ is given to the perineum. ${ }^{6-8}$ Inhalation injury is one of the most severe forms of burn injury and it is associated with a high rate of mortality. ${ }^{9}$ The presence of inhalation injury is strongly associated with increased morbidity and mortality up to $20 \%$. The incidence of pneumonia rises to $40 \%$. It involves damage to the respiratory tract and lungs by heat, smoke, and toxicants. $^{10}$

A severe burn patient with advanced age, large total body surface area, and inhalation injury have a high risk of substantial complication and death. ${ }^{11}$ Burn cases feature varied and significant individual differences. Patients with the same total body surface area and depth of burn may have different outcomes. ${ }^{12}$ The general physical response to burns is reported to be diverse. Therefore, reliable parameters to trace the general clinical course, particularly the pathological course of inflammation is required. Existing injury scores such as burn injury severity score and Ryan score have failed to demonstrate the severity of inflammation. ${ }^{13}$ Inflammatory markers like $\mathrm{C}$-reactive protein and procalcitonin do not correlate with the outcomes of severe burn injury. ${ }^{13}$ Various laboratory variables, including complete blood count, urea and creatinine levels can help in demonstrating the severity of inflammation.

Haemoglobin levels decrease gradually to below control levels by 4 th post-burn day in the non-survivors. Patients with severe burns demonstrate a steady drop in haemoglobin levels until death. 14 Whereas patients of burn injury who survive show relatively less drop in haemoglobin values and gradually the haemoglobin level increases. ${ }^{2,14}$ Persistent anaemia plagues critically ill burn patients even after resolution of their initial acute event. ${ }^{15}$ Red cell distribution width (RDW) provides useful information about burn severity and outcome. It can be used as a monitoring index in burns patients. Burn patients with higher RDW have increased mortality, third-degree burns, higher TBSA, increased infection rate, and higher length of hospital stay. ${ }^{2}$ There are significant differences in RDW values of survivors and non-survivors. ${ }^{16}$ It has been found that RDW is an independent predictor of burn severity. It is significantly higher in patients with increased TBSA and burns due to inhalation injury. ${ }^{17}$

The platelet count is significantly low in non-survivor burn patients, whereas it starts increasing by day 5 in patients who survived the burn injuries. An increase in platelet count represents a normal response to various inflammatory stimuli. Whereas thrombocytopenia is considered to be an important sign predicting worsening of the course of the disease thereby increased mortality. ${ }^{2,18}$ In non-survivors gradual decline in platelet count is observed and the minimal platelet count is observed before the death of the burns patients. While in survivors gradual rise in platelet count is observed. ${ }^{2,19-23}$ In the recent past, RDW platelet ratio (RPR) has gained substantial attention as a prognostic marker of various medical conditions such as severe burn injury, patent ductus arteriosus, hepatic fibrosis and cirrhosis in chronic hepatitis B, myocardial infarction, and non-alcoholic fatty liver disease. Higher RPR predicts higher fibrosis. ${ }^{2,24}$ Non-survivor patients have a higher RPR as compared to survivors after burn injury. Recent studies have shown that RPR is an independent prognostic marker. ${ }^{2}$ Mean platelet volume (MPV) correlates linearly with BAUX score thereby indicating that a rise in MPV correlates with poor prognosis in burn patients. ${ }^{25}$ White blood cell count (WBC) is not very much clinically reliable in predicting bloodstream infection. ${ }^{2,26}$

Acute renal failure (ARF) is one of the major complications of burns and it is accompanied by a high mortality rate. Reduced urine output despite adequate fluid administration is usually the first sign of ARF. This is followed by a rise in serum creatinine and urea concentration. The prognosis of burn patients with acute renal failure is usually unfavourable. Patients having serum creatinine more than $1.5 \mathrm{mg} / \mathrm{del}$ above the initial values have mortality rates high as $72.7 \%$, much higher than patients who have no renal dysfunction. ${ }^{2,27}$

\section{MATERIAL AND METHODS}

Our study was a retrospective study from $1^{\text {st }}$ March 2018 to $31^{\text {st }}$ May 2018. The sample size was 100 burn patients. There were 60 females and 40 males. Two patients, including one male and one female, succumbed to burn injury before day 5 hence were not included in our study. A total of 34 patients died within 40 days after the initial injury. We noted the clinical details like age, gender, burn index, inhalation injury if present, complete blood count, blood urea and serum creatinine levels. Medical notes were used to retrospectively record the patients. Their blood samples were routinely collected between 5 am and 7 am during $5^{\text {th }}, 7^{\text {th }}, 10^{\text {th }}$ and $20^{\text {th }}$-day post-burn. The medical records were used to document the time from injury to adverse events. The follow up to evaluate endpoint was defined as the time interval from admission to death or discharge.

The inclusion criteria included burns patients of all age groups admitted to burns department from $1^{\text {st }}$ March 2018 to $31^{\text {st }}$ May with variable \%TBSA burned. The excluded patients had known the previous history of cardiac disease, kidney disease, hemolytic anaemia, bone marrow arrest and inflammatory diseases.

\section{Statistical Analysis}

Categorical variables were presented in number and percentage (\%) and continuous variables were presented as mean \pm SD. Quantitative variables were compared using an independent t-test between the two groups. Qualitative variables were 
correlated using Chi-Square test/ Fisher's Exact test. Receiver operating characteristic curve was used to find out cut off point of parameters for predicting mortality. Kaplan Meier survival analysis, the curve was used to find out survival rate at different time point. Univariate and multivariate cox-proportional hazard regression was used to find out the significant risk factors of mortality rate. A p-value of $<0.05$ was considered statistically significant. The data were entered in the MS EXCEL spreadsheet and analysis was done using Statistical Package for Social Sciences (SPSS) version 21.0.

\section{RESULTS}

Our study was conducted in a tertiary hospital in north India. We included the data from $1^{\text {st }}$ March 2018- $31^{\text {st }}$
May 2018. The sample size was of 100 burn patients. Twelve variables were regarded as potential predictors of outcome(Table 1). The data were then classified into day 5 , day 7, day 10 and day 20 datasets to reflect the association of the laboratory variables at different time points with the endpoint.

The following parameters showed significant differences between survivors and non-survivors on days 5, 7, 10 and 20: Gender, burn index (BI), inhalation injury, haemoglobin, red cell distribution width (RDW), platelets, RDW to platelet ratio (RPR), mean platelet volume (MPV), urea and creatinine. No significant difference was observed between survivors and non-survivors in terms of age and white blood cell count.

Table 1: Demographics and clinical characteristics of patients from follow-up results on days 5,7,10 and 20. The variables measured on days 5,7,10 and 20 postburn received Student's t-test or Pearson's chi squared test. Data were present as mean \pm SD, or number (\%). BI indicates burn index; WBC, white blood cell count; RDW, red cell distribution width; RPR, RDW to platelet ratio; MPV, mean platelet volume.

\begin{tabular}{|c|c|c|c|c|c|c|c|c|c|c|c|c|}
\hline & \multicolumn{3}{|c|}{ Day 5} & & \multicolumn{3}{|c|}{ Day 10} & \multicolumn{3}{|c|}{ Day 20} \\
\hline & $\begin{array}{l}\text { Survivor } \\
66\end{array}$ & $\begin{array}{c}\text { Non Sur- } \\
\text { vivor } \\
32\end{array}$ & $\mathbf{P}$ & $\begin{array}{l}\text { Survivor } \\
66\end{array}$ & $\begin{array}{c}\text { Non Survi- } \\
\text { vor } \\
31\end{array}$ & $\mathbf{P}$ & $\begin{array}{c}\text { Survivor } \\
66\end{array}$ & $\begin{array}{c}\text { Non Sur- } \\
\text { vivor } \\
26\end{array}$ & $\mathbf{P}$ & $\begin{array}{c}\text { Survivor } \\
66\end{array}$ & $\begin{array}{l}\text { Non Survi- } \\
\text { vor } \\
19\end{array}$ & $\mathbf{P}$ \\
\hline $\begin{array}{l}\text { Age } \\
\text { (Years) }\end{array}$ & $26.89+19.77$ & $33.6+20.2$ & 0.121 & $26.89+19.77$ & $33.8+20.13$ & 0.113 & $26.89+19.77$ & $35 \cdot 73+21.85$ & 0.064 & $26.89+19.77$ & $39 \cdot 3+22.4$ & 0.021 \\
\hline Gender & $\mathrm{M}$ & M & 0.003 & M & M & 0.004 & M & M & 0.009 & M & M & 0.035 \\
\hline & $33 \quad 33$ & $26 \quad 6$ & & $33 \quad 33$ & 25 & & 33 & $21 \quad 5$ & & $33 \quad 33$ & 15 & \\
\hline BI & $26.56+11.98$ & $50.12+17 \cdot 4$ & 0.001 & $26.56+11.98$ & $48.67 \pm 15.76$ & 0.001 & $26.56+11.98$ & $44 \cdot 57 \pm 13 \cdot 36$ & 0.001 & $26.56+11.98$ & $40.21 \pm 11.95$ & 0.001 \\
\hline $\begin{array}{l}\text { Inhalation } \\
\text { Injury }\end{array}$ & $2(3 \%)$ & $5(15.6 \%)$ & 0.023 & $2(3 \%)$ & $5(16.12 \%)$ & 0.020 & $2(3 \%)$ & $5(19.2 \%)$ & 0.008 & $2(3 \%)$ & $3(15.8 \%)$ & 0.037 \\
\hline $\begin{array}{l}\text { WBC }(\mathrm{X} \\
\left.10^{9}\right)\end{array}$ & $13 \cdot 49 \pm 9 \cdot 50$ & $16.04 \pm 11.3$ & 0.244 & $11.61 \pm 10.95$ & $17.24 \pm 13.84$ & 0.032 & $11.29 \pm 10.70$ & $15.4 \pm 13.90$ & 0.233 & $11.47 \pm 13.36$ & $12.60 \pm 12.85$ & 0.744 \\
\hline $\begin{array}{l}\text { Hemo- } \\
\text { globin (g/ } \\
\text { dl) }\end{array}$ & $10.60 \pm 2.30$ & $8.93 \pm 2.71$ & 0.002 & $12.99 \pm 1.99$ & $6.91 \pm 1.62$ & 0.001 & $13.14 \pm 1.91$ & $6.87 \pm 1.31$ & 0.001 & $13.28 \pm 1.89$ & $6.48 \pm 1.28$ & 0.001 \\
\hline RDW & $13.79 \pm 1.91$ & $15 \cdot 35 \pm 2.1$ & 0.001 & $13 \cdot 75 \pm 2.66$ & $15 \cdot 32 \pm 2.24$ & 0.005 & $13.64 \pm 2.03$ & $15 \cdot 7 \pm 2.02$ & 0.001 & $13.54 \pm 2.46$ & $15.89 \pm 2.16$ & 0.001 \\
\hline $\begin{array}{l}\text { Platelets } \\
\left(\mathrm{X}_{10} / \mathrm{L}\right)\end{array}$ & $226 \pm 157 \cdot 51$ & $55.40 \pm 36.7$ & 0.001 & $241.8 \pm 133$ & $51.74 \pm 29.43$ & 0.001 & $285.2 \pm 158.2$ & $48.38 \pm 33.21$ & 0.001 & $295 \pm 117.19$ & $46 \pm 25.6$ & 0.001 \\
\hline RPR & $0.18 \pm 0.35$ & $0.56 \pm 0.58$ & 0.001 & $0.08 \pm 0.06$ & $0.48 \pm 0.43$ & 0.001 & $0.09 \pm 0.13$ & $0.58 \pm 0.54$ & 0.001 & $0.06 \pm 0.03$ & $0.97 \pm 1.69$ & 0.001 \\
\hline MPV & $9.62 \pm 1.48$ & $11.10 \pm 0.77$ & 0.001 & $9 \cdot 38 \pm 1.35$ & $11.33 \pm 0.75$ & 0.001 & $9 \cdot 34 \pm 1.45$ & $11.45 \pm 0.83$ & 0.001 & $9.03 \pm 1.20$ & $11.45 \pm 0.83$ & 0.001 \\
\hline $\begin{array}{l}\text { Urea (mg/ } \\
\text { dl) }\end{array}$ & $37.44 \pm 11.74$ & $51.01 \pm 22.6$ & 0.001 & $35 \cdot 49 \pm 11.74$ & $59.5^{8} \pm 20.47$ & 0.001 & $33.18 \pm 9.81$ & $61.61 \pm 15.92$ & 0.001 & $33 \cdot 36 \pm 9 \cdot 74$ & $72.68 \pm 20.20$ & 0.001 \\
\hline $\begin{array}{l}\text { Creatinine } \\
(\mathrm{mg} / \mathrm{dl})\end{array}$ & $0.71 \pm 0.26$ & $0.93 \pm 0.43$ & 0.002 & $0.73 \pm 0.44$ & $0.99 \pm 0.68$ & 0.025 & $0.63 \pm 0.28$ & $0.91 \pm 0.59$ & 0.002 & $0.46 \pm 0.11$ & $1.45 \pm 2.57$ & 0.002 \\
\hline
\end{tabular}


ROC curves of Age, Percentage of burn, Haemoglobin, RDW, Platelets, RPR, MPV, WBC, Urea and Creatinine and adverse outcome in a severe burn injury

The age, $\%$ of burns, RDW, RPR, MPV, WBC, urea and creatinine values were considerably high in patients with mortality in the day 5, day 7, day 10 and day 20 datasets, whereas the haemoglobin, platelet values were low. As shown in Table 2. the areas under the ROC curves of the age and WBC were poor with AUC of 0.598 (0.494 to 0.696) and 0.55 ( 0.447 to 0.651 ) respectively in the day 5 dataset (Figure 1), 0.601 (0.496 to 0.699$)$ and 0.644 (0.540 to 0.738 ) respectively in the day 7 dataset (Figure 3), 0.621 (0.514 to 0.720) and 0.561 ( 0.453 to 0.664$)$ respectively in the day 10 dataset and 0.635 (0.524 to 0.737) (Figure 5) and 0.505 (0.395 to 0.615) in the day 20 dataset (Figure 7). Areas under the ROC curves of \% of burns, haemoglobin, RDW, platelets, RPR, MPV, urea and creatinine were 0.874 (0.791 to 0.932), 0.898 ( 0.820 to 0.950$), 0.873$ (0.791 to 0.932$), 0.732$ (0.633 to 0.816$), \quad 0.864 \quad(0.780$ to 0.925$), \quad 0.873$ ( 0.791 to 0.932$), 0.809$ ( 0.717 to 0.881$), 0.712$ ( 0.611 to 0.799$)$ and 0.673 ( 0.571 to 0.764$)$ respectively for mortality prediction in the day 5 dataset (Figure 2), 0.87 (0.786 to 0.930), 0.996 ( 0.954 to 1.000$), 0.765$ (0.668 to 0.845$), 0.978$ (0.925 to 0.997$), 0.978$ ( 0.925 to 0.997$), 0.915$ ( 0.841 to 0.962$)$, 0.882 ( 0.800 to 0.938 ) and 0.588 (0.483 to 0.687 ) respectively for mortality prediction in the day 7 dataset (Figure 4), 0.845 (0.754 to 0.912 ), 0.997 (0.954 to 1.000 ), 0.793 (0.696 to 0.871$), 0.951$ (0.885 to 0.985$), 0.958$ $(0.895$ to 0.989$), 0.904 \quad(0.825$ to 0.956$), 0.939$ (0.869 to 0.978$)$ and 0.59 ( 0.482 to 0.691$)$ respectively for mortality prediction in the day 10 dataset (Figure 6) and 0.787 (0.685 to 0.869$), 0.999$ (0.956 to 1.000), 0.835 (0.738 to 0.906$), 0.994$ (0.945 to 1.000$), 0.998$ (0.954 to 1.000$), 0.976 \quad(0.917$ to 0.997$), 0.976$ ( 0.917 to 0.997$)$ and 0.757 ( 0.652 to 0.844$)$ respectively for mortality prediction in the day 20 dataset (Figure 8). The maximum value of Youden index was used as the criterion for selecting the optimum cut-off point to divide the variables to the high value group and the low value group. The Youden index was represented by the formula Youden index $=$ sensitivity + specificity -1 . Percentage of burns, haemoglobin, RDW, platelets, RPR, MPV, urea and creatinine were statistically significant for mortality prediction in the day 5 dataset with sensitivity of $68.75 \%, 81.25 \%, 93.75 \%, 81.25 \%, 100 \%$, $87.5 \%, 68.75 \%$ and $65.62 \%$ respectively and specificity of $90.91 \%, 86.36 \%$, and $59.09 \%, 84.85 \%, 68.18 \%, 72.73 \%$, $72.73 \%$ and $65.15 \%$ respectively. $\%$ of burns, haemoglobin, RDW, platelets, RPR, MPV, WBC and urea were statistically significant for mortality prediction in the day 7 dataset with sensitivity of $67.74 \%, 96.77 \%, 93.55 \%, 100 \%, 100 \%$, $93.55 \%, 38.71 \%$ and $83.87 \%$ respectively, and specificity of $90.91 \%, 96.97 \%$, and $62.12 \%, 90.91 \%, 93.94 \%, 81.54 \%$, $89.39 \%$ and $86.36 \%$ respectively. \% of burns, haemoglobin,
RDW, platelets, RPR, MPV, and urea were statistically significant for mortality prediction in the day 10 datasets with sensitivity of $61.54 \%, 100 \%, 100 \%, 100 \%, 100 \%, 92.31 \%$, and $88.46 \%$ respectively, and specificity of $90.91 \%, 98.48 \%$, $62.12 \%, 83.33 \%, 86.36 \%, 86.36 \%$, and $92.42 \%$ respectively. $\%$ of burns, haemoglobin, RDW, platelets, RPR, MPV, urea and creatinine were statistically significant for mortality prediction in the day 20 datasets with sensitivity of $78.95 \%$, $100 \%, 100 \%, 100 \%, 100 \%, 94.74 \%, 89.47 \%$ and $63.16 \%$ respectively, and specificity of $65.15 \%, 98.48 \%$, and $69.7 \%$, $95.45 \%, 96.97 \%, 95.45 \%, 96.97 \%$ and $90.91 \%$ respectively

(Table 2).

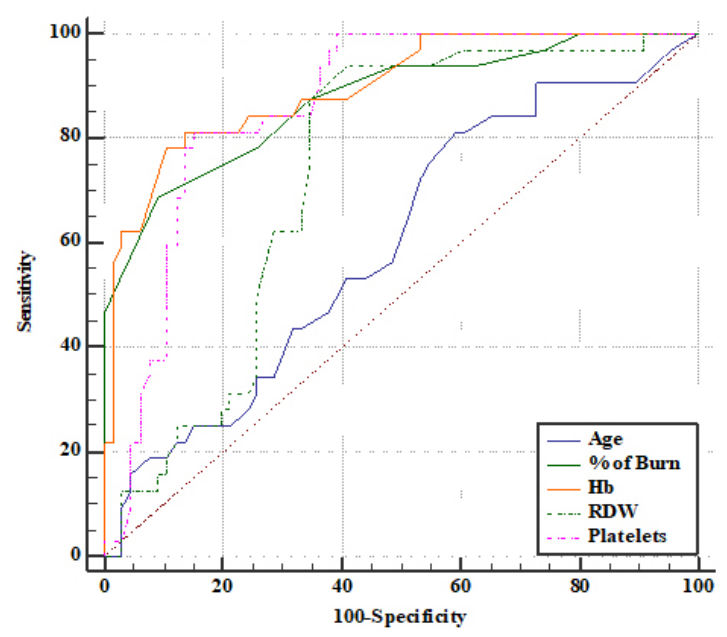

Figure 1: Receiver operating characteristic curve of Age, Percentage of burn, Hemoglobin (Hb), RDW and Platelets on days 5 for prediction of adverse endpoint at 40 days.

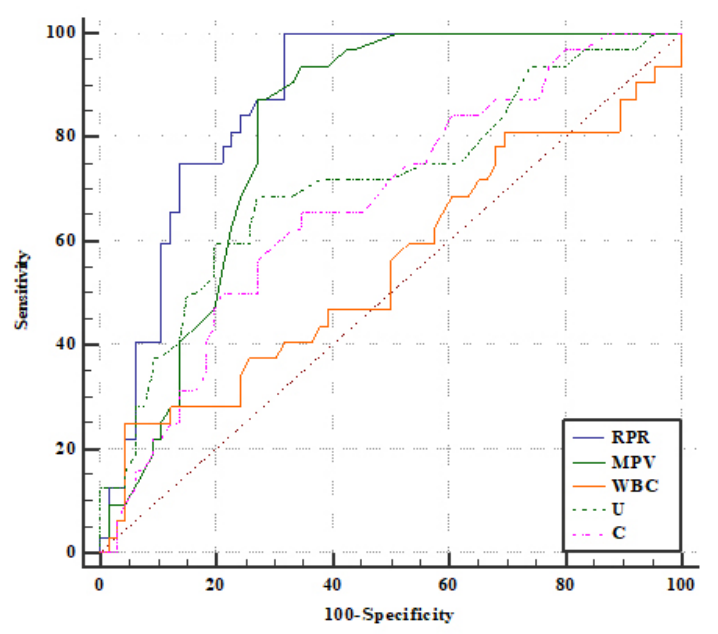

Figure 2: Receiver operating characteristic curve of RPR, MPV, WBC, Urea (U) and Creatinine (C) on days 5 for prediction of adverse endpoint at 40 days. 


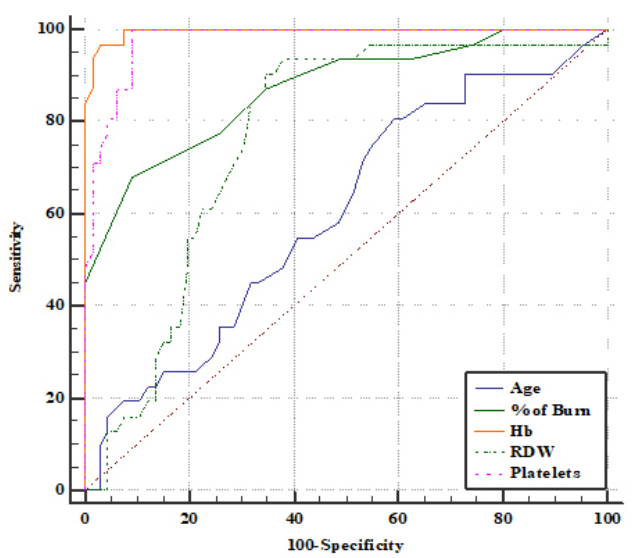

Figure 3: Receiver operating characteristic curve of Age, Percentage of burn, Hemoglobin $(\mathrm{Hb}), \mathrm{RDW}$ and Platelets on days 7 for prediction of adverse endpoint at 40 days.

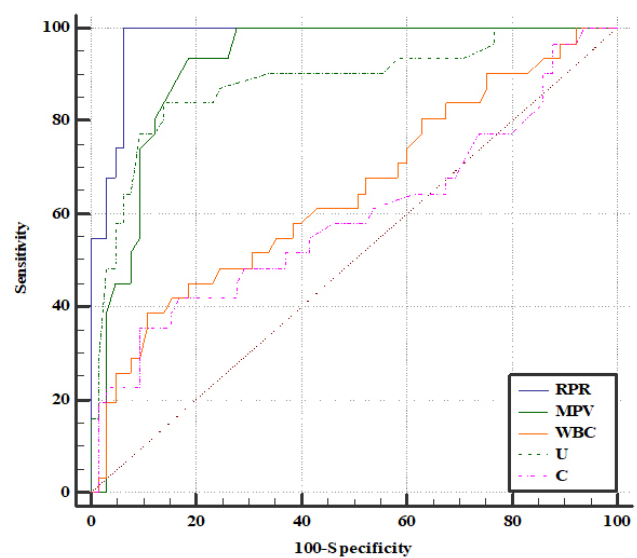

Figure 4: Receiver operating characteristic curve of RPR, MPV, WBC, Urea (U) and Creatinine (C) on days 7 for prediction of adverse endpoint at 40 days.

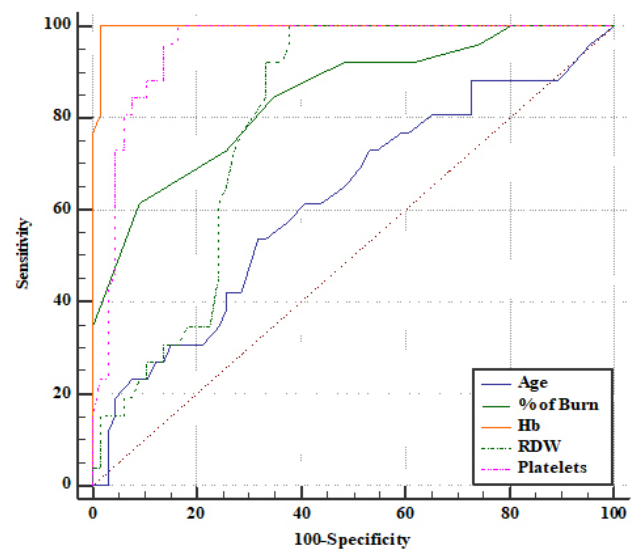

Figure 5: Receiver operating characteristic curve of Age, Percentage of burn, Hemoglobin ( $\mathrm{Hb}), \mathrm{RDW}$ and Platelets on days 10 for prediction of adverse endpoint at 40 days.

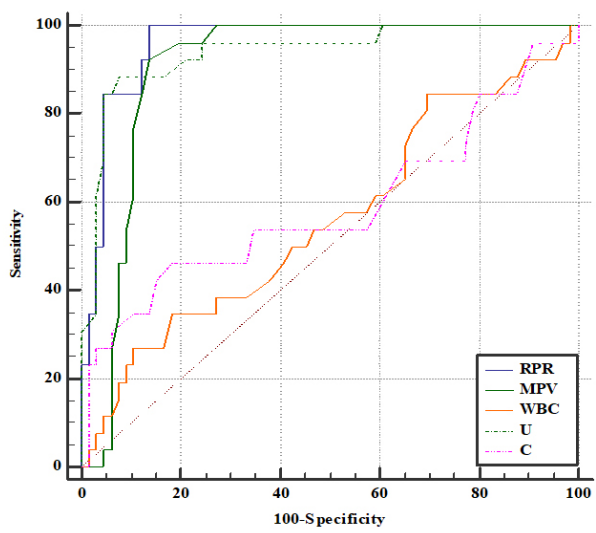

Figure 6: Receiver operating characteristic curve of RPR, MPV, WBC, Urea (U) and Creatinine (C) on day 10 for prediction of adverse endpoint at 40 days.

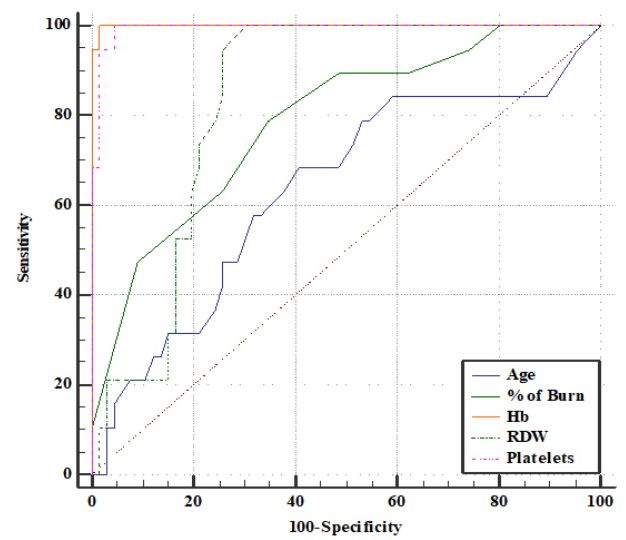

Figure 7: Receiver operating characteristic curve of Age, Percentage of burn, Hemoglobin ( $\mathrm{Hb}), \mathrm{RDW}$ and Platelets on day 20 for prediction of adverse endpoint at 40 days.

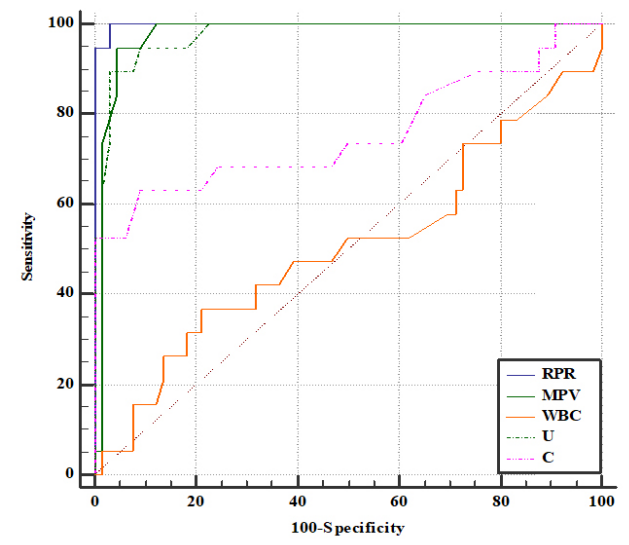

Figure 8: Receiver operating characteristic curve of RPR, MPV, WBC, Urea(U) and Creatinine (C) on day 20 for prediction of adverse endpoint at 40 days. 
Table 2: Diagnostic information for the prediction of mortality on days 5,7,10 and 20

\begin{tabular}{|c|c|c|c|c|c|}
\hline Day & Variable & $\begin{array}{l}\text { Optimal cut off } \\
\text { point }\end{array}$ & Sensitivity (\%) & Specificity (\%) & $\operatorname{AUC}(95 \% \mathrm{CI})$ \\
\hline Day & Age & $>21$ & 81.25 & 40.91 & $0.598(0.494$ to 0.696$)$ \\
\hline \multirow{9}{*}{5} & $\%$ of Burn & $>40$ & 68.75 & 90.91 & $0.874(0.791$ to 0.932$)$ \\
\hline & $\mathrm{Hb}$ & $\leq 8.6$ & 81.25 & 86.36 & $0.898(0.820$ to 0.950$)$ \\
\hline & RDW & $>13.6$ & 93.75 & 59.09 & $0.732(0.633$ to 0.816$)$ \\
\hline & Platelets & $\leq 87$ & 81.25 & 84.85 & $0.864(0.780$ to 0.925$)$ \\
\hline & RPR & $>0.1141$ & 100 & 68.18 & $0.873(0.791$ to 0.932$)$ \\
\hline & MPV & $>10.4$ & 87.5 & 72.73 & $0.809(0.717$ to 0.881$)$ \\
\hline & WBC & $>24$ & 25 & 95.45 & $0.55(0.447$ to 0.651$)$ \\
\hline & Urea & $>41$ & 68.75 & 72.73 & $0.712(0.611$ to 0.799$)$ \\
\hline & Creatinine & $>0.76$ & 65.62 & 65.15 & $0.673(0.571$ to 0.764$)$ \\
\hline \multirow[t]{10}{*}{ Day 7} & Age & $>21$ & 80.65 & 40.91 & $0.601(0.496$ to 0.699$)$ \\
\hline & $\%$ of Burn & $>40$ & 67.74 & 90.91 & $0.87(0.786$ to 0.930$)$ \\
\hline & $\mathrm{Hb}$ & $\leq 9.1$ & 96.77 & 96.97 & $0.996(0.954$ to 1.000$)$ \\
\hline & RDW & $>13.4$ & 93.55 & 62.12 & $0.765(0.668$ to 0.845$)$ \\
\hline & Platelets & $\leq 104$ & 100 & 90.91 & $0.978(0.925$ to 0.997$)$ \\
\hline & RPR & $>0.1364$ & 100 & 93.94 & $0.978(0.925$ to 0.997$)$ \\
\hline & MPV & $>10.4$ & 93.55 & 81.54 & $0.915(0.841$ to 0.962$)$ \\
\hline & WBC & $>14.8$ & 38.71 & 89.39 & $0.644(0.540$ to 0.738$)$ \\
\hline & Urea & $>43$ & 83.87 & 86.36 & $0.882(0.800$ to 0.938$)$ \\
\hline & Creatinine & $>0.91$ & 35.48 & 89.39 & $0.588(0.483$ to 0.687$)$ \\
\hline \multirow[t]{10}{*}{ Day 10} & Age & $>31$ & 53.85 & 68.18 & $0.621(0.514$ to 0.720$)$ \\
\hline & $\%$ of Burn & $>40$ & 61.54 & 90.91 & $0.845(0.754$ to 0.912$)$ \\
\hline & $\mathrm{Hb}$ & $\leq 9.2$ & 100 & 98.48 & $0.997(0.954$ to 1.000$)$ \\
\hline & RDW & $>13.5$ & 100 & 62.12 & $0.793(0.696$ to 0.871$)$ \\
\hline & Platelets & $\leq 130$ & 100 & 83.33 & $0.951(0.885$ to 0.985$)$ \\
\hline & RPR & $>0.1035$ & 100 & 86.36 & $0.958(0.895$ to 0.989$)$ \\
\hline & MPV & $>10.5$ & 92.31 & 86.36 & $0.904(0.825$ to 0.956$)$ \\
\hline & WBC & $>12.4$ & 34.62 & 81.82 & $0.561(0.453$ to 0.664$)$ \\
\hline & Urea & $>43$ & 88.46 & 92.42 & $0.939(0.869$ to 0.978$)$ \\
\hline & Creatinine & $>0.71$ & 46.15 & 81.82 & $0.59(0.482$ to 0.691$)$ \\
\hline \multirow[t]{10}{*}{ Day 20} & Age & $>27$ & 68.42 & 59.09 & $0.635(0.524$ to 0.737$)$ \\
\hline & $\%$ of Burn & $>30$ & 78.95 & 65.15 & $0.787(0.685$ to 0.869$)$ \\
\hline & $\mathrm{Hb}$ & $\leq 9.8$ & 100 & 98.48 & $0.999(0.956$ to 1.000$)$ \\
\hline & RDW & $>13.8$ & 100 & 69.7 & $0.835(0.738$ to 0.906$)$ \\
\hline & Platelets & $\leq 97$ & 100 & $95 \cdot 45$ & $0.994(0.945$ to 1.000$)$ \\
\hline & RPR & $>0.1379$ & 100 & 96.97 & $0.998(0.954$ to 1.000$)$ \\
\hline & MPV & $>10.7$ & 94.74 & 95.45 & $0.976(0.917$ to 0.997$)$ \\
\hline & WBC & $>10.6$ & 36.84 & 78.79 & $0.505(0.395$ to 0.615$)$ \\
\hline & Urea & $>52$ & 89.47 & 96.97 & $0.976(0.917$ to 0.997$)$ \\
\hline & Creatinine & $>0.61$ & 63.16 & 90.91 & $0.757(0.652$ to 0.844$)$ \\
\hline
\end{tabular}

CI: Confidence interval. The maximum value of Youden index (sensitivity +specificity -1) was used as the criteria for selecting the optimal cutoff point. 


\section{Survival analysis for predicting severe burn mortality rates}

The age, \% of burns, haemoglobin, RDW, PLT, RPR, MPV, WBC, urea, creatinine, gender, and inhalation injury of days 5 and days 7 were significant risk factors of mortality according to the univariate regression analysis results $(\mathrm{P}$ $<0.05)$. However, on multivariate Cox regression, only $\%$ of burn, haemoglobin and urea were significant risk factors of mortality in the day 5 dataset with adjusted $\mathrm{HR}=2.991$, 95\% CI: $1.1-8.132, \mathrm{P}=0.032$; adjusted $\mathrm{HR}=3.361,95 \% \mathrm{CI}$ : $1.005-11.242, \mathrm{P}=0.049$ and adjusted $\mathrm{HR}=3.569,95 \% \mathrm{CI}$ : 1.356-9.392, $\mathrm{P}=0.010$ respectively (Figure 9,10,11) and \% of burn, haemoglobin, RDW and creatinine were significant risk factors of mortality in the day 7 dataset with adjusted $\mathrm{HR}=3.089,95 \% \mathrm{CI}: 1.126-8.478, \mathrm{P}=0.029$; adjusted $\mathrm{HR}$
$=116.918,95 \% \mathrm{CI}: 5.135-2661.933, \mathrm{P}=0.003$, adjusted $\mathrm{HR}$ $=0.093,95 \% \mathrm{CI}: 0.01-0.828, \mathrm{P}=0.033$ and adjusted HR $=2.416,95 \%$ CI: $1.004-5.814, \mathrm{P}=0.049$ respectively $($ Figure $12,13,14,15)$. The $\%$ of burns, haemoglobin, RDW, PLT, RPR, MPV, urea, creatinine, gender, and inhalation injury of days 10 were significant risk factors of mortality according to the univariate regression analysis results $(\mathrm{P}<0.05)$. However, on multivariate Cox regression, none of the factors was the independent risk factor of mortality. The $\%$ of burns, RDW, MPV, urea, creatinine, and gender of days 20 were significant risk factors of mortality according to the univariate regression analysis results $(\mathrm{P}<0.05)$. However, on multivariate Cox regression, none of the factors was the independent risk factor of mortality. (Table 3, Table 4).

Table 3: Results of univariate and multivariate Cox proportional-hazards regression for the analysis of the effects of baseline variables on an adverse endpoint on day 5 and day 7.

\begin{tabular}{|c|c|c|c|c|c|c|c|c|}
\hline \multirow[b]{3}{*}{ Variable } & \multicolumn{4}{|c|}{ Day 5} & \multicolumn{4}{|c|}{ Day 7} \\
\hline & \multicolumn{2}{|c|}{ Univariate } & \multicolumn{2}{|c|}{ Multivariate } & \multicolumn{2}{|c|}{ Univariate } & \multicolumn{2}{|l|}{ Multivariate } \\
\hline & $\operatorname{HR}(95 \%)$ & P value & $\operatorname{HR}(95 \%)$ & P value & $\operatorname{HR}(95 \%)$ & P value & $\operatorname{HR}(95 \%)$ & P-value \\
\hline $\begin{array}{l}\operatorname{Age}(>\text { cut off } \\
\text { point })\end{array}$ & $2.515(1.035-6.112)$ & 0.0419 & $\begin{array}{c}1.188(0.378- \\
3.736)\end{array}$ & 0.768 & $\begin{array}{c}2.428(0.996- \\
5.92)\end{array}$ & 0.0512 & - & - \\
\hline $\begin{array}{l}\% \text { of Burn }(>\text { cut off } \\
\text { point })\end{array}$ & $\begin{array}{c}10.628(4.978- \\
22.691)\end{array}$ & $<.0001$ & $\begin{array}{l}2.991(1.1- \\
8.132)\end{array}$ & 0.032 & $\begin{array}{c}10.323(4.81- \\
22.154)\end{array}$ & $<.0001$ & $3.089(1.126-8.478)$ & .029 \\
\hline $\mathrm{Hb}$ (>cut off point) & $\begin{array}{c}12.002\left(4.895^{-}\right. \\
29.429)\end{array}$ & $<.0001$ & $\begin{array}{c}3.361\left(1.005^{-}\right. \\
11.242)\end{array}$ & 0.049 & $\begin{array}{c}163.9\left(21.904^{-}\right. \\
1226.405)\end{array}$ & $<.0001$ & $116.918(5.135-2661.933)$ & .003 \\
\hline $\begin{array}{l}\text { RDW (>cut off } \\
\text { point) }\end{array}$ & $14.561(3 \cdot 473-61.049)$ & 0.0002 & $\begin{array}{c}3.271(0.607- \\
17.634)\end{array}$ & 0.168 & $\begin{array}{c}15.708\left(3.74^{-}\right. \\
65.977)\end{array}$ & 0.0002 & $0.093(0.01-0.828)$ & .033 \\
\hline $\begin{array}{l}\text { Platelets (>cut off } \\
\text { point) }\end{array}$ & $\begin{array}{l}11.602(4.736- \\
28.422)\end{array}$ & $<.0001$ & $\begin{array}{c}1.289(0.48- \\
3.461)\end{array}$ & 0.614 & $\begin{array}{c}408.652(7.729- \\
21606.155)\end{array}$ & 0.0030 & $\begin{array}{c}78.751(\mathrm{o}- \\
2.05660277676892 \mathrm{E}+55)\end{array}$ & .945 \\
\hline $\begin{array}{l}\text { RPR(>cut off } \\
\text { point })\end{array}$ & $\begin{array}{c}79 \cdot 365(4 \cdot 506- \\
1397.823)\end{array}$ & 0.0028 & $\begin{array}{c}32923.767(0- \\
7.22 \mathrm{E}+80)\end{array}$ & 0.908 & $\begin{array}{c}612.036\left(7.473^{-}\right. \\
50128.744)\end{array}$ & 0.0043 & $\begin{array}{c}3681.694(0- \\
7 \cdot 37463111179202 \mathrm{E}+56)\end{array}$ & .896 \\
\hline $\begin{array}{l}\text { MPV(>cut off } \\
\text { point })\end{array}$ & $\begin{array}{c}11.507(4.024- \\
32.907)\end{array}$ & $<.0001$ & $\begin{array}{c}2.456(0.78- \\
7.728)\end{array}$ & 0.125 & $\begin{array}{c}32.267\left(7.663^{-}\right. \\
135.866)\end{array}$ & $<.0001$ & $1.414(0.17-7.22 \mathrm{E}+80)$ & .749 \\
\hline $\begin{array}{l}\text { WBC (>cut off } \\
\text { point) }\end{array}$ & $4.063(1.818-9.08)$ & 0.0006 & $\begin{array}{l}0.887\left(0.317^{-}\right. \\
2.478)\end{array}$ & 0.819 & $\begin{array}{c}3.526(1.706- \\
7.29)\end{array}$ & 0.0007 & $0.511(0.202-1.291)$ & .156 \\
\hline $\begin{array}{l}\text { Urea(>cut off } \\
\text { point })\end{array}$ & $4.296(2.028-9.098)$ & 0.0001 & $\begin{array}{c}3.569(1.356- \\
9.392)\end{array}$ & 0.010 & $\begin{array}{c}14.878\left(5.667^{-}\right. \\
39.063)\end{array}$ & $<.0001$ & $2.121(0.631-7.135)$ & .224 \\
\hline $\begin{array}{l}\text { Creatinine }(>\text { cut } \\
\text { off point) }\end{array}$ & $2.723(1.311-5.655)$ & 0.0072 & $\begin{array}{c}0.792(0.326- \\
1.92)\end{array}$ & 0.605 & $\begin{array}{c}3.615(1.724- \\
\left.7 \cdot 4^{-}\right)\end{array}$ & 0.0007 & $2.416(1.004-5.814)$ & .049 \\
\hline \multicolumn{9}{|l|}{ Gender } \\
\hline Female & 1 & & 1 & & 1 & & 1 & \\
\hline Male & $0.289(0.119-0.704)$ & 0.006 & $\begin{array}{c}1.101(0.382- \\
3.171)\end{array}$ & 0.859 & $\begin{array}{c}0.299(0.123- \\
0.73)\end{array}$ & .008 & $1.25(0.307-5.091)$ & $\cdot 755$ \\
\hline Inhalation injury & $2.638(1.013-6.871)$ & 0.047 & $\begin{array}{c}3.949(1.002- \\
15.572)\end{array}$ & 0.050 & $\begin{array}{c}2.763(1.058- \\
7.218)\end{array}$ & .038 & $2.138(0.571-7.998)$ & .259 \\
\hline
\end{tabular}


Table 4: Results of univariate and multivariate Cox proportional-hazards regression for the analysis of the effects of baseline variables on an adverse endpoint on day 10 and day 20.

\begin{tabular}{|c|c|c|c|c|c|c|c|c|}
\hline \multirow[b]{3}{*}{ Variable } & \multicolumn{4}{|c|}{ Day 10} & \multicolumn{4}{|c|}{ Day 20} \\
\hline & \multicolumn{2}{|l|}{ Univariate } & \multicolumn{2}{|l|}{ Multivariate } & \multicolumn{2}{|l|}{ Univariate } & \multicolumn{2}{|l|}{ Multivariate } \\
\hline & $\operatorname{HR}(95 \%)$ & Pvalue & $\operatorname{HR}(95 \%)$ & Pvalue & $\operatorname{HR}(95 \%)$ & Pvalue & $\operatorname{HR}(95 \%)$ & P-value \\
\hline $\begin{array}{l}\operatorname{Age}(>\text { cut off } \\
\text { point })\end{array}$ & $1.999(0.924-4.324)$ & .078 & - & - & $2.598(0.987-6.837)$ & .053 & - & - \\
\hline $\begin{array}{l}\% \text { of } \\
\text { Burn }(>\text { cut off } \\
\text { point })\end{array}$ & $8.685(3.912-19.282)$ & $<.0001$ & $1.455(0.522-4.056)$ & .474 & $5 \cdot 702(1.89-17.206)$ & .0020 & $2.249(0.662-7.644)$ & .194 \\
\hline $\begin{array}{l}\mathrm{Hb}(>\text { cut off } \\
\text { point })\end{array}$ & $\begin{array}{l}2486.741(1.624- \\
3807997.657)\end{array}$ & .037 & $\begin{array}{c}2283.048\left(\mathrm{o}^{-}\right. \\
716482687839.265)\end{array}$ & .439 & $\begin{array}{l}8590.636(0.005- \\
14581015230.597)\end{array}$ & .216 & - & - \\
\hline $\begin{array}{l}\text { RDW (>cut off } \\
\text { point) }\end{array}$ & $\begin{array}{l}\text { 71.777(3.026- } \\
1702.624)\end{array}$ & .008 & $\begin{array}{c}12.937(\mathrm{o}- \\
25155292267108500000)\end{array}$ & .905 & $\begin{array}{l}111.353(2.356- \\
5262.383)\end{array}$ & .017 & $\begin{array}{c}39204.216(\mathrm{o}- \\
5.14946838713053 \mathrm{E}+84)\end{array}$ & .911 \\
\hline $\begin{array}{l}\text { Platelets (>cut } \\
\text { off point) }\end{array}$ & $\begin{array}{l}234.032\left(5.191^{-}\right. \\
10551.121)\end{array}$ & .005 & $\begin{array}{c}18.467(\mathrm{o}- \\
8.83444794017216 \mathrm{E}+59)\end{array}$ & .966 & $\begin{array}{l}2880.117(0.137- \\
60385774.969)\end{array}$ & .117 & - & - \\
\hline $\begin{array}{l}\mathrm{RPR}(>\text { cut off } \\
\text { point })\end{array}$ & $\begin{array}{c}313.08\left(5.205^{-}\right. \\
18833.238)\end{array}$ & .006 & $\begin{array}{c}0.54(0- \\
3.33858710843644 E+61)\end{array}$ & .993 & $\begin{array}{l}4741.753(0.036- \\
632323856.551)\end{array}$ & .160 & - & - \\
\hline $\begin{array}{l}\text { MPV(>cut off } \\
\text { point) }\end{array}$ & $35.292(8.29-150.247)$ & $<.0001$ & $1.335(0.227-7.22 \mathrm{E}+8 \mathrm{o})$ & .749 & $\begin{array}{l}105.849(13.915- \\
805.198)\end{array}$ & $<.0001$ & 11.331(o.639-200.899) & .098 \\
\hline $\begin{array}{l}\text { WBC (>cut off } \\
\text { point) }\end{array}$ & $2.06(0.917-4.625)$ & .080 & - & - & $1.927(0.759-4.897)$ & .168 & - & - \\
\hline $\begin{array}{l}\text { Urea (>cut off } \\
\text { point) }\end{array}$ & $\begin{array}{c}32.55\left(9.637^{-}\right. \\
109.934)\end{array}$ & $<.0001$ & $1.044(0.285-3.824)$ & .948 & $\begin{array}{l}62.568\left(14.093^{-}\right. \\
277.783)\end{array}$ & $<.0001$ & $4.204(0.539-32.813)$ & .171 \\
\hline $\begin{array}{l}\text { Creatinine } \\
\text { (>cut off } \\
\text { point) }\end{array}$ & $3.031(1.399-6.567)$ & .005 & $1.175(0.48-2.877)$ & .724 & $9.015(3.527-23.044)$ & $<.0001$ & $0.976(0.337-2.826)$ & .965 \\
\hline Gender & & & & & & & & \\
\hline Female & 1 & & 1 & & 1 & & 1 & \\
\hline Male & $0.363(0.146-0.905)$ & .030 & $1.64(0.552-4.87)$ & .373 & $0.313(0.104-0.943)$ & .039 & $0.883(0.273-2.858)$ & .835 \\
\hline $\begin{array}{l}\text { Inhalation } \\
\text { injury }\end{array}$ & $3.601(1.353-9.58)$ & .010 & $1.309(0.422-4.064)$ & .642 & $3.169(0.922-10.89)$ & .067 & - & - \\
\hline
\end{tabular}

\section{Kaplan Meier Survival analysis curve}

Kaplan Meier Survival analysis curve was plotted for parameters which proved to be a statistically significant independent prognostic factor on a multivariate analysis curve. These parameters included the \% of burns, haemoglobin and urea on day 5 and $\%$ of burns, haemoglobin, RDW and creatinine on day 7.

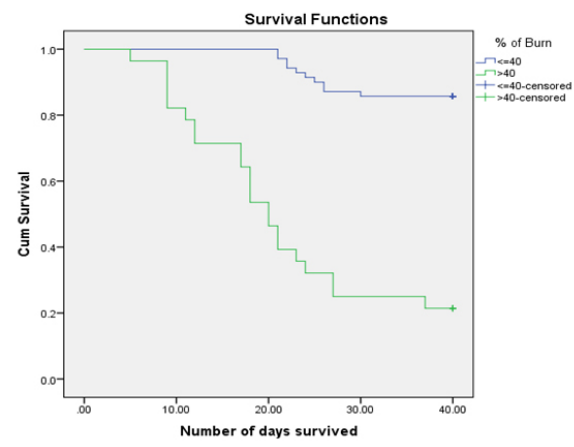

Figure 9: Kaplan Meier survival curve for \% of burns on day 5.

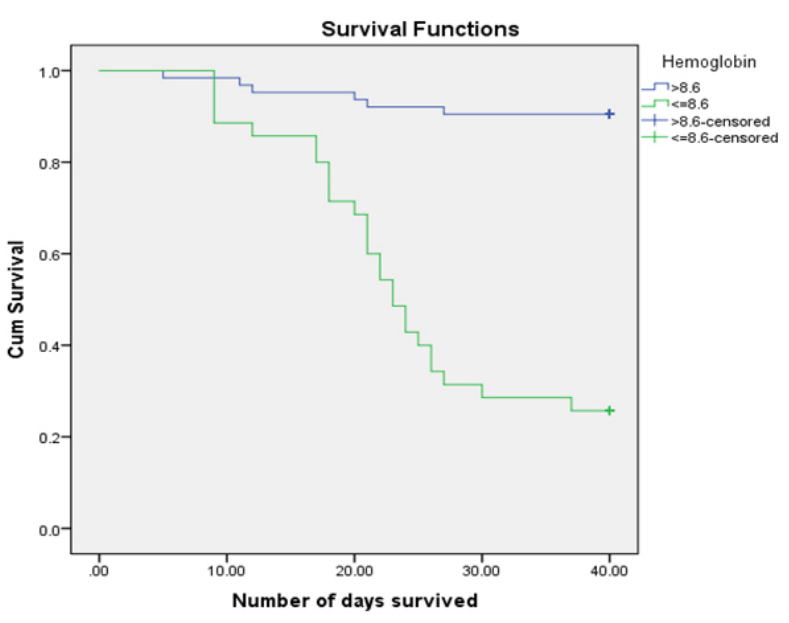

Figure 10: Kaplan Meier survival curve for haemoglobin on day 5 . 


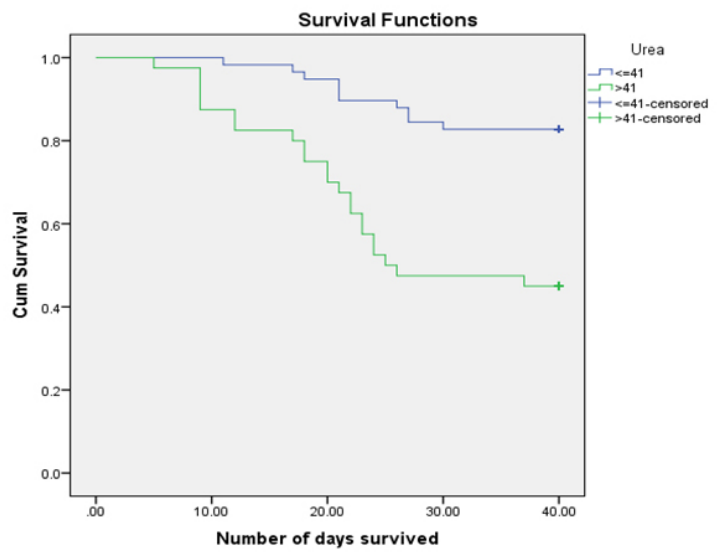

Figure 11: Kaplan Meier survival curve for urea levels on day 5.

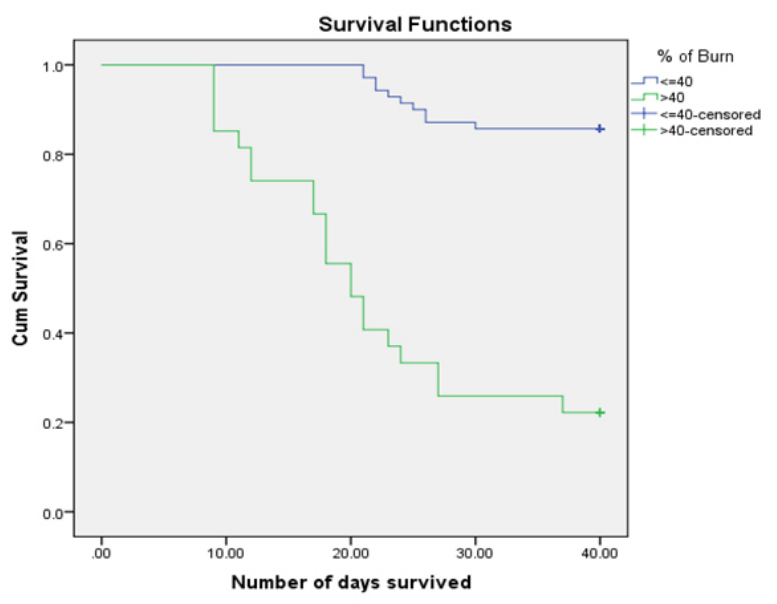

Figure 12: Kaplan Meier survival curve for $\%$ of burns on day 7

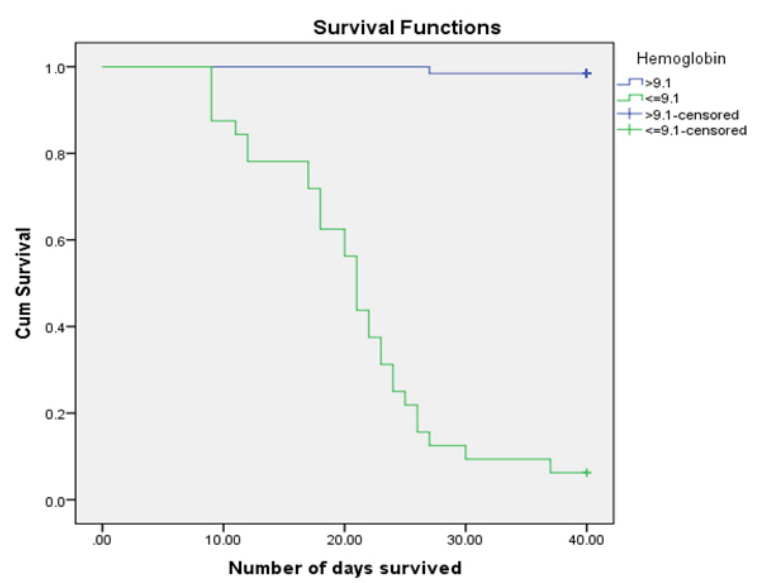

Figure 13: Kaplan Meier survival curve for haemoglobin on day 7 .

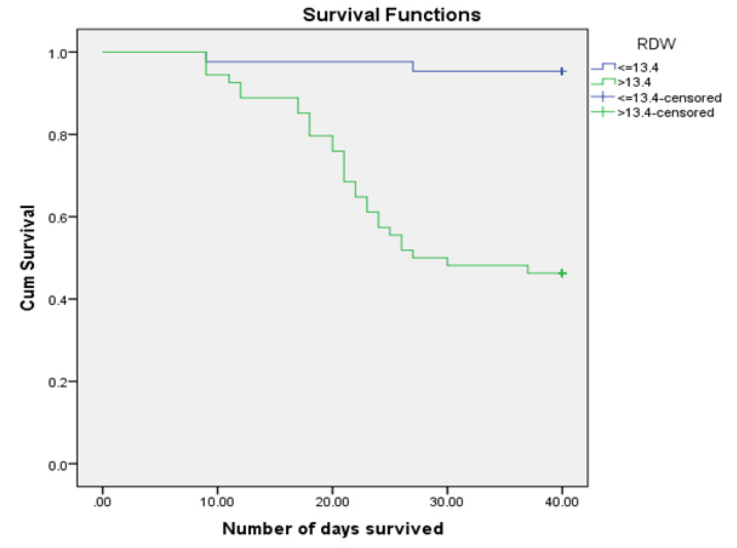

Figure 14: Kaplan Meier survival curve for RDW on day 7

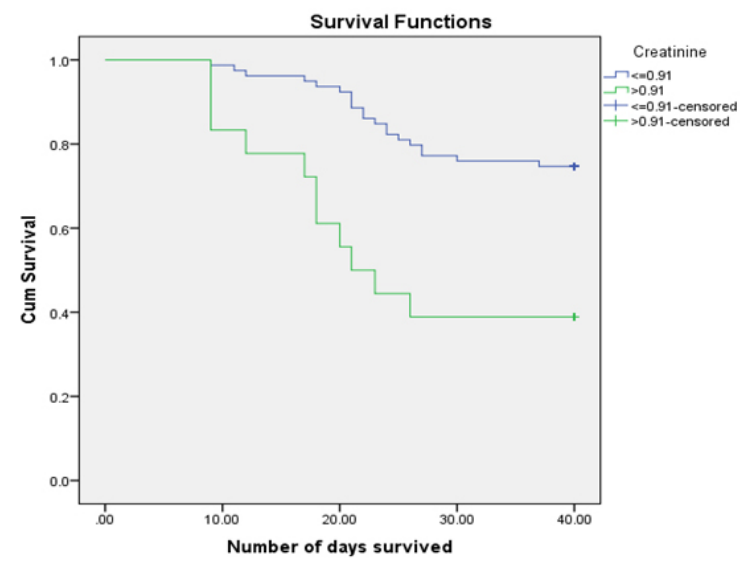

Figure 15: Kaplan Meier survival curve for creatine on day 7.

\section{Kaplan Meier Survival Curve for RPR}

Our study showed that RPR was not a statistically significant independent risk factor in multivariate-Cox proportionalhazards regression in burns patients, though it was statistically significant on univariatecox proportional-hazards regression curve.

Divided by the optimal RPR cutoff values, the Kaplan-Meier plots for the two categories at two-time points indicated that RPR values of more than the cutoff value have lower survival rates than the RPR values less than the cutoff value. On day 5, the 40-day mortality rate of the low RPR group was $0 \%$ and that of the high RPR group was 59.3\% (Figure 16). On day 7 , the mortality was $0 \%$ in the low RPR group and $88.6 \%$ in the high RPR group (Figure 17), on day 10 (Figure 18), the mortality was $0 \%$ in the low RPR group and $74.3 \%$ in the high RPR group and on day 20 , the mortality was $0 \%$ in the low RPR group and $90.5 \%$ in the high RPR group (Figure 19). The difference between the low and high RPR groups in terms of the difference in time points was statistically significant $(\mathrm{P}<0.05)$. 


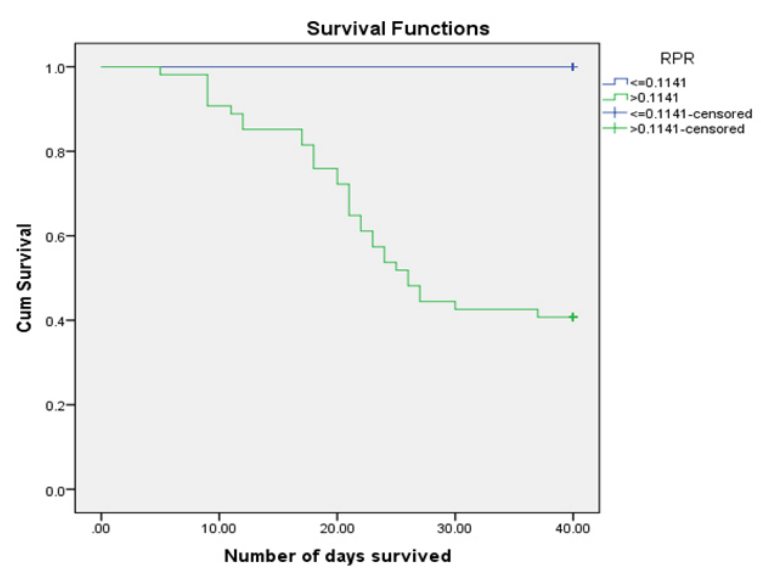

Figure 16: Kaplan - Mier survival curve for RPR higher or lower than 0.1141 at day 5 .

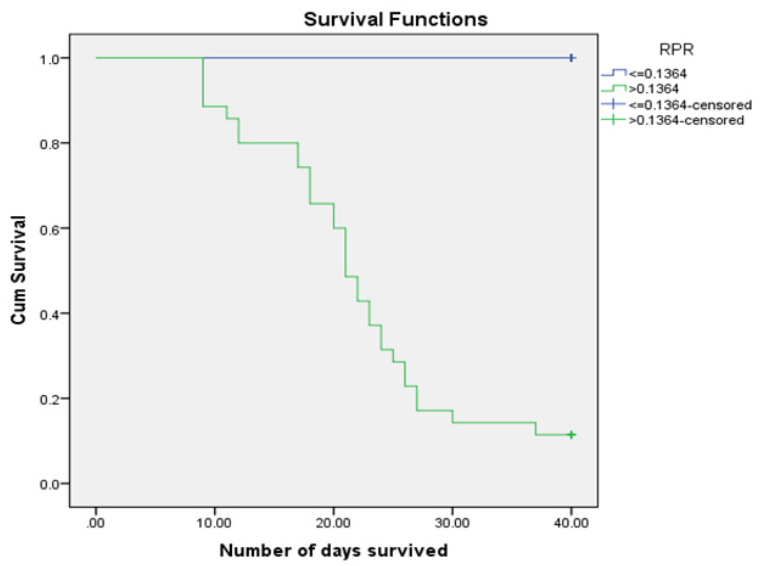

Figure 17: Kaplan - Mier survival curve for RPR higher or lower than 0.1364 at day 7 .

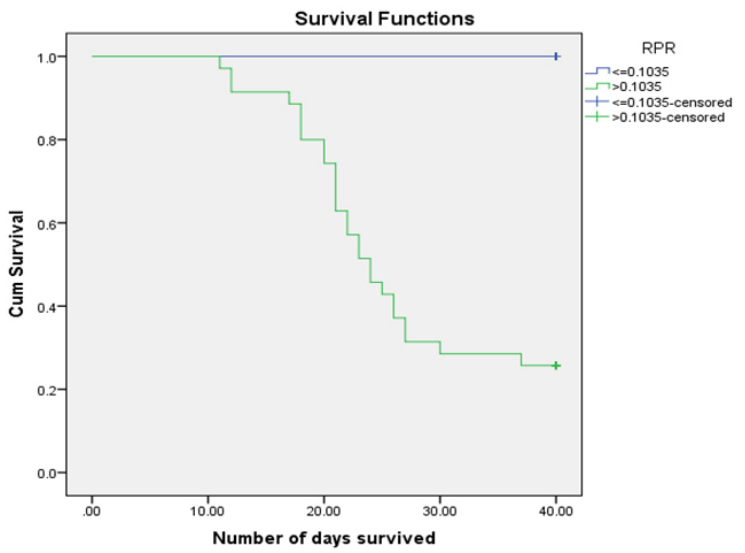

Figure 18: Kaplan - Mier survival curve for RPR higher or lower than 0.1364 at day 10 .

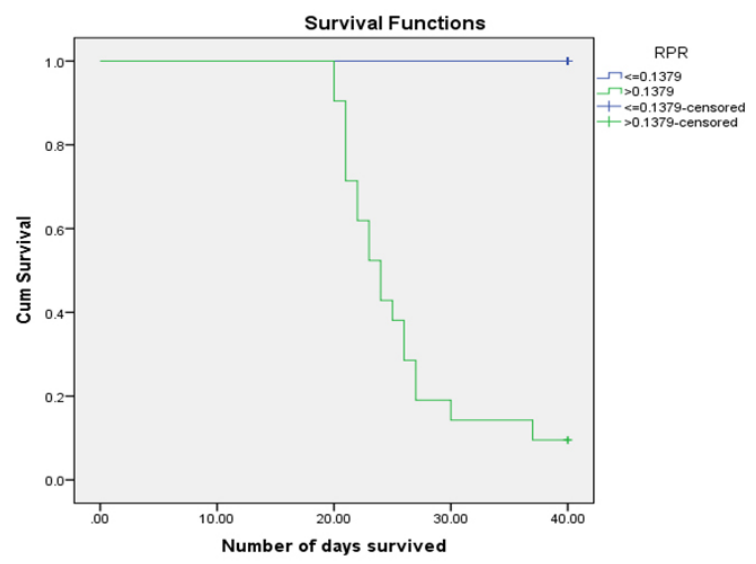

Figure 19: Kaplan - Mier survival curve for RPR higher or lower than 0.1364 at day 20 .

\section{DISCUSSION}

An increased burn index is an independent prognostic factor in burn patients. We observed in our study that with the higher the burn index, the rate of mortality is high. Mean burn index in survivors was $26.5 \%$, whereas in non-survivors it was $50.1 \%$ in day 5 data set (Table 1). In Kaplan Meier survival curve patients with $>40 \%$ TBSA had a greater risk of mortality. The area under the receiver operating characteristic curve for a percentage of burns was 0.87 (95\% CI, 0.7910.932 ) on day 5 post-burn (Figure 1, Table 2). Percentage of burns were a significant risk factor of mortality according to the univariate and multivariate cox regression curve (Table 3, Figure 9 and Figure 12).

The mean haemoglobin value dropped in non-survivors from $8.93 \mathrm{~g} / \mathrm{Dl}$ on day 5 to $6.4 \mathrm{~g} / \mathrm{Dl}$ on day 20 . Whereas in survivors the mean haemoglobin values gradually increased from $10.6 \mathrm{~g} / \mathrm{Dl}$ on day 5 to $13.28 \mathrm{~g} / \mathrm{Dl}$ on day 20 respectively. (Table 1) By day 20 the receiver operating characteristic curve analysis demonstrated $100 \%$ sensitivity at a cut off value of $\leq 9.8 \mathrm{~g} / \mathrm{Dl}$ for haemoglobin (Table 2, Figure 7). Low haemoglobin values were a significant risk factor of mortality according to univariate and multivariate cox regression curve. On the Kaplan Meier survival curve, it was seen that patient with haemoglobin values of $<8.6 \mathrm{~g} / \mathrm{dl}$ had an increased risk of mortality (Table 3, Table 4, Figure 10 and Figure 13). Significant differences in haemoglobin values between survivors and non-survivors is also reported. ${ }^{2}$ In survivors, the mean haemoglobin value on day 3 and day 7 was $130.62 \mathrm{~g} / 1$ and $105.97 \mathrm{~g} / \mathrm{l}$. whereas in non-survivors the haemoglobin values were $124.34 \mathrm{~g} / 1$ and $93.56 \mathrm{~g} / 1$ on day 3 and 7 respectively.

We observed that in non-survivors the RDW values were significantly higher as compared to survivors. By day 20 mean RDW in non-survivors were $15.89 \%$ and in survivors being $13.54 \%$. $(\mathrm{p}=0.000)$ Table 1 . ROC curve analysis demonstrat- 
ed $100 \%$ sensitivity at a cut off value of $13.8 \%$ on day 20 . (Figure 7, Table 2). High RDW values were a significant risk factor of mortality according to univariate and multivariate cox regression curve. Kaplan Meier survival curve showed that patients with RDW $>13.4 \%$ had a greater risk of succumbing to burn injury (Table 3, Table 4, Figure 14). Many studies suggest the importance of RDW as a prognostic indicator in various chronic diseases. ${ }^{2,16,17} \mathrm{RDW}$ value is a good predictor of mortality in the oesophagal burn. ${ }^{17} \mathrm{An}$ RDW of over $12.20 \%$ showed an increased risk of mortality to oesophagal burn.

We noticed a gradual increase in mean platelet values among the post-burn survivors on days 5, 7, 10 and 20 being $226 \mathrm{X}$ $10^{9} / \mathrm{L}, 241.8 \times 10^{9} / \mathrm{L}, 285.2 \times 10^{9} / \mathrm{L}$ and $295 \times 10^{9} / \mathrm{L}$ respectively. Whereas the mean platelet values decreased on days $5,7,10$ and 20 in non-survivors being $55 \mathrm{X} 10^{9} / \mathrm{L}, 51.74 \mathrm{X}$ $10^{9} / \mathrm{L}, 48.38 \mathrm{X} 10^{9} / \mathrm{L}$ and $46 \mathrm{X} 10^{9} / \mathrm{L}$ respectively. ROC curve analysis expressed $100 \%$ sensitivity at a cut off value of $\leq$ $97 \mathrm{X} 10^{9} / \mathrm{L}$ on day 20 with the area under ROC curve being 0.994(95 CI, 0.945-1.000). Low platelet values were a significant risk factor of mortality according to univariate cox regression curve (Table 1-4, Figure 7). The platelet count in survivors and non-survivors are correlated. ${ }^{19}$ They showed that out of 206 burn patients with low platelet count $(<1.5$ lakh/ $\left.\mathrm{mm}^{3}\right) 159(62.11 \%)$ were non-survivors. Whereas 47 $(13.9 \%)$ were survivors. The findings correlated with our study.

It was seen that RDW to platelet ratio (RPR) was higher in non-survivors as compared to survivors. ROC curve analysis demonstrated $100 \%$ sensitivity at a cut off value of 0.136 for RPR. The area under the ROC curve is 0.998. (95\% CI, $0.945-1.000$ ) (Table 2). In our study RPR values proved to be a significant risk factor of mortality according to univariate cox regression curve. RPR values were not statistically significant independent prognostic factors based on multivariate Cox regression curve (Table 3, Table 4). According to Kaplan- Mier survival curves on day 5,7,10 and 20 mortality was $0 \%$ in the low RPR group. Whereas on the same day's mortality was $59.3 \%, 88.6 \%, 74.3 \%$ and $90.5 \%$ respectively in high RPR group (Figure 16 and 19).

According to study RPR is an independent risk factor on both unilabiate as well as multivariate Cox regression curve. ${ }^{2}$ Our study showed that RPR was not an independent risk factor in multivariate cox regression curve. We observed that the mean platelet value of $>10.4$ optimal cut off point had 0.809 (0.717-0.881) area under the ROC curve with the sensitivity of $87.5 \%$ on day 5 . It was a statistically significant predictor of mortality (Table 2, Figure 2).

It was seen that in non-survivors the blood urea and serum creatinine values gradually increased. By day 20 mean values of blood urea and serum creatinine were $72.68 \mathrm{mg} / \mathrm{dl}$ and $1.45 \mathrm{mg} / \mathrm{dl}$ respectively. Whereas in survivors the mean val- ues of blood urea and serum creatinine were $33.36 \mathrm{mg} / \mathrm{dl}$ and $0.46 \mathrm{mg} / \mathrm{dl}$ by day $20(\mathrm{p}=0.0001)$ (Table 1$)$. On the Kaplan Meier curve, it was observed that patients with blood urea levels of more than $41 \mathrm{mg} / \mathrm{dl}$ had increased risk of mortality. Blood urea and serum creatinine values proved to be statistically significant independent mortality predictors and risk factors of mortality according to unilabiate and multivariate cox regression curve (Table 2, Figure 8, Figure 11).

The significant cut off values for serum creatinine for predicting early acute kidney injury and thereby increased risk of mortality ranged from $0.85 \mathrm{mg} / \mathrm{dl}-1.15 \mathrm{mg} / \mathrm{dl} .{ }^{28}$ It was a significant biomarker predicting acute kidney injury. Area under ROC curve for blood urea was $0.541(\mathrm{p}=0.523) .{ }^{29}$ It was not a significant biomarker for predicting acute kidney injury, unlike our study. Our study revealed both blood urea as well as serum creatinine as statistically significant independent risk factors for mortality in burn patients.

\section{CONCLUSION}

The results indicated that parameters like haemoglobin, RDW, blood urea and serum creatinine and \% of burns are statistically significant independent mortality predictors in burn patients. Whereas; RPR did not prove to be a statistically significant independent mortality predictor. It is suggested that future randomized studies using common and clinically relevant endpoints to evaluate and look for a new, reliable, effective and readily available prognostic factors.

\section{Acknowledgement: NIL}

\section{Conflict of Interest: NIL}

\section{Source of Funding: NIL}

\section{REFERENCES}

1. Gupta JL, Makhija LK, Bajaj SP. National programme for prevention of burn injuries. Indian J Plast Surg 2010 Sep;43(Suppl):S6S10.

2. Qiu L, Chen C, Li S, Wang C, Guo F, Peszel A, et al. Prognostic values of red blood cell distribution width, platelet count, and red cell distribution width-to-platelet ratio for severe burn injury. Sci Rep 2017;7:13720.

3. Griffiths RW, Laing JE. A burn formula in clinical practice. Ann R Coll Surg Engl 1981;63(1):50-3.

4. Saha D. Indian women most prone to deat by fire. India Spend $2017 ; 1$.

5. Karimi K, Faraklas I, Lewis G, Ha D, Walker B, Zhai Y, et al. Increased mortality in women: sex differences in burn outcomes. Burns Trauma 2017;5:18.

6. Tagami T, Matsui H, Fushimi K, Yasunaga H. Validation of the prognostic burn index: a nationwide retrospective study. Burns 2015;41(6):1169-75.

7. Stavropoulou V, Daskalakis J, Ioannovich J. A new prognostic burn index. Ann Medit Burns Club 1993;6(2):1-7.

8. Sheppard NN, Hemington-Gorse S, Shelley OP, Philp B, 
Dziewulski P. Prognostic scoring systems in burns: a review. Burns 2011;37(8):1288-95.

9. Helbawy RH, Ghareeb FM. Inhalation injury as a prognostic factor for mortality in burn patients. Ann Burns Fire Disast $2011 ;(2): 82-88$.

10. Monteiro D, Silva I, Egipto P, Magalhães A, Filipe R, Silva A, et al. Inhalation injury in a burn unit: a retrospective review of prognostic factors. Ann Burns Fire Disast 2017;30(2):121-25.

11. Jeschke MG, Pinto R, Kraft R, Nathens AB, Finnerty CC, Gamelli RL, et al. . Inflammation and the Host Response to Injury Collaborative Research Program. Morbidity and survival probability in burn patients in modern burn care. Crit Care Med 2015;43(4):808-15.

12. Duke JM, Randall SM, Wood FM, Boyd JH, Fear MW. Burns and long-term infectious disease morbidity: A population-based study. Burns: J Int Soc Burn Inj 2017;43(2):273-81.

13. Guo F, Wang X, Huan J, Liang X, Chen B, Tang J, Gao C. Association of platelet counts decline and mortality in severely burnt patients. J Crit Care 2012;27(5):529.e1-7.

14. James WG, Wilkerson V, Anderson A. The anaemia of thermal injury. I. Studies of pigment excretion. J Clin Invest 1951;30(2):181-90.

15. Slabber P, Farina Z, Allorto N, Rodseth RN. Predicting postoperative haemoglobin changes after a burn surgery. S Afr Med J 2017;107(5):424-27.

16. Guo J, Qin Q, Hu H, Zhou D, Sun Y, Deng A. Red Cell Distribution Width (RDW) as a Prognostic Tool in Burn Patients. Clin Lab 2016;62(10):1973-1978.

17. Aydin E, Beser OF, Sazak S, Duras E. Role of RDW in Prediction of Burn after Caustic Substance Ingestion. Children (Basel) 2017;5(1):5.

18. Pavic M, Milevoj L. Platelet count monitoring in burn patients. Biochemia Medica 2007;17(2):212-19.

19. Gajbhiye AS, Meshram MM, Kathod AP. Platelet count as a prognostic indicator in burn septicemia. Indian J Surg 2013;75(6):444-8.
20. Sarda DK, Dagwade AM, Lohiya S, et al. Evaluation of platelet count as a prognostic indicator in early detection of post-burn septicaemia. Bombay Hosp J 2005;47(3):3-6.

21. Cohen P, Gardner FH. Thrombocytopenia as a laboratory sign and complication of a gram-negative bacteremic infection. Arch Intern Med 1966;117:113-23.

22. Maduli IC, Patil A, Pardhan NR, Panigraphy PK, Mukherjee LM. Evaluation of burn sepsis concerning platelet count as a prognostic indicator. IJS 1999;61(4):235-8.

23. Housinger TA, Brinkerhoff C, Warden GD. The relationship between platelet count, sepsis, and survival in pediatric burn patients. Arch Surg 1993;128(1):65-6.

24. Zhou WJ, Yang J, Zhang G, Hu ZQ, Jiang YM, Yu F. Association between red cell distribution width-to-platelet ratio and hepatic fibrosis in nonalcoholic fatty liver disease: A cross-sectional study. Medicine (Baltimore) 2019;98(30):e16565.

25. Sofiya C, Pushpa B. Significance of platelet indices in the burn patient. Pathology Update: Trop J Path Micro 2017;3(4):401405.

26. Murray CK, Hoffmaster RM, Schmit DR, Hospenthal DR, Ward JA, Cancio LC, et al. Evaluation of white blood cell count, neutrophil percentage, and elevated temperature as predictors of bloodstream infection in burn patients. Arch Surg 2007;142(7):639-42.

27. Chrysopoulo MT, Jeschke MG, Dziewulski P, Barrow RE, Herndon DN. Acute renal dysfunction in severely burned adults. J Trauma 1999;46(1):141-4.

28. Yang HT, Yim H, Cho YS, Kym D, Hur J, Kim JH, et al. Assessment of biochemical markers in the early post-burn period for predicting acute kidney injury and mortality in patients with major burn injury: comparison of serum creatinine, serum cystatin$\mathrm{C}$, plasma and urine neutrophil gelatinase-associated lipocalin. Crit Care 2014;18(4): R151.

29. Kym D, Cho YS, Yoon J, Yim H, Yang HT. Evaluation of diagnostic biomarkers for acute kidney injury in major burn patients. Ann Surg Treat Res 2015;88(5):281-8. 